\title{
Efficiency of Different Preparations of Botulinum Toxin Type A, Xeomin and Dysport, in the Management of Spastic Upper Limb After Stroke
}

\author{
MARIUS NICOLAE POPESCU1,2\#, RAZVAN COSMIN PETCA ${ }^{1,3 *}$, CRISTINA BEIU1*, MIHAI CRISTIAN DUMITRASCU1,4*, \\ AIDA PETCA ${ }^{1,2}$, CLAUDIA MEHEDINTU1,5, PATRICIA DELIA FARCASANU ${ }^{1}$, FLORICA SANDRU ${ }^{1,2}$ \\ ${ }^{1}$ Carol Davila University of Medicine and Pharmacy, 8 Eroii Sanitari Blvd., 050474 Bucharest, Romania \\ 2Elias University Emergency Hospital, 17 Marasti Blvd., 011461 Bucharest, Romania \\ ${ }^{3}$ Prof. Th. Burghele Clinical Hospital, 20 Panduri Str., 050653, Bucharest, Romania \\ ${ }^{4}$ Bucharest University Emergency Hospital, 169 Splaiul Independenei, 050098, Bucharest, Romania \\ ${ }^{5}$ Malaxa Clinical Hospital, 12 Vergului Str., 022441, Bucharest, Romania
}

The present study quantifies the effect of the two botulinum toxin type A products, Xeomin and Dysport, with approval from the National Agency for Medicines and Medical Devices of Romania (ANMDMR), for the treatment of the spastic upper limb following a stroke. The results obtained in the presentstudy show a good efficiency of using both products in the spasticity of the upper limb, and a maintenance of the results obtained for both products for a minimum period of 3 months. Also, at higher doses, the results of the study show better improvement of spasticity and upper limb function on the evaluation scales, but the local effect is not maintained for a longer period.

Keywords: toxinum botulinum type A, Xeomin, Dysport, spasticity

Post-stroke spasticity is a common condition which accounts for long-term disabilities. It represents a highly complex phenomenon that is difficult to understand and evaluate in clinical practice. Currently, there is no universal consensus on the definition of spasticity. The definition of spasticity is rather an evolving process, as is our understanding of the pathophysiological mechanisms and clinical interpretations of this condition [1].

The condition may occur secondary to a stroke, but it is just one of the many consequences of the central motor neuron syndrome. Traditionally, it is clinically easy to identify and the most frequent definition given by the American Academy of Neurology is the one described by Lance in 1980: Spasticityis a motor disorder characterized by a speed dependentincrease in stretch reflexes (muscle tone), with exaggerated tendon reflexes resulting from a hyperexcitability of the stretch reflexes as a component of the central motor neuron syndrome [2].

Detailed clinical evaluation is vital to identify patientcentered spasticity issues and other factors that contribute to its impact, such as muscle retraction, weakness, and dexterity loss. While some authors consider that spasticity has a significant contribution to limiting activity, others have found that muscle weakness is a more important factor in limiting the performance of active tasks in the upper limb [3-6].

Rehabilitation goals for spastic upper limb management include restoring active function, if there is any return of motor function, or, if not possible, improving passive function to facilitate limb care $[7,8]$.

There are a variety of treatments available to control spasticity. Nonpharmacological treatments, including physical therapies, occupational therapies and complementary and alternative medicine are effective adjuvants to oral medicines and interventional therapies.

While each of the therapies mentioned above have proven to be effective in treating spasticity, the treatment itself comes with its own adverse effects. In general, oral agents are more affordable in the short term and easier to use, but have undesirable systemic effects, which may outweigh the potential benefits they can provide $[9,10]$.

Toxinum botulinum type $A$ is currently the most widely used treatment for focal spasticity [11-13], as in many neurological movement disorders including tremor, tics and myoclonus [14-18]. Toxinum botulinum is the strongest neurotoxin with a lethal effect at an estimated dose of approximately $0.09-0.15 \mu \mathrm{g}$ for intravenous or intramuscular administration, 0.70 to $0.90 \mu \mathrm{g}$ for the inhaled substance, and $70 \mu \mathrm{g}$ for oral administration [19].

The first reports on the possible therapeutic use of toxinum botulinum date back to 1817 when German poet and medical officer Christian Andreas Justinus Kerner extracted the toxin from infected sausages and showed in animal studies that it could cause skeletal muscle paralysis and loss of parasympathetic function [20]. In 1944, Edward Schant cultivated Clostridium botulinum, isolated the toxin and developed the bulk purification scheme for toxinum botulinum. In 1949, Arnold Burgen discovered that toxinum botulinum blocks neuromuscular transmission by inhibiting acetylcholine release [21].

It is now well established that toxinum botulinum is a protein neurotoxin produced by an anaerobic bacterium, Clostridium botulinum [22-24]. It acts primarily by inhibiting the release of acetylcholine from the presynaptic terminal, thereby blocking peripheral cholinergic transmission at the neuromuscular junction [13,24].

Currently there are 4 different commercially available preparations, containing toxinum botulinum in many western countries (table 1).

Toxinum botulinum is taken up by the neuromuscular junction within 12 hours and the installation of the effect appears gradually for 4 to 7 days. It blocks synaptic neuromuscular transmission, causing local muscle relaxation. This results in a biomechanical change in the function of the muscles allowing their extension. In addition, local weakness in spastic muscles facilitates exercises to strengthen antagonistic muscles, and thus making possible the restoration of agonist-antagonist 


\begin{tabular}{|l|l|}
\hline $\begin{array}{c}\text { Toxinum botulinum } \\
\text { type }\end{array}$ & Product \\
\hline Onabotulimumtoxin $A$ & Botox (Allergan, Inc, Irvine, CA) \\
\hline Abobotulinumtoxin $A$ & Dysport (Ipsen Ltd., Paris, France) \\
\hline Incobotulinumtoxin $A$ & $\begin{array}{c}\text { Xeomin (Merz Pharmaceuticals, Frankfurt, } \\
\text { Germany) }\end{array}$ \\
\hline Rimabotulinumtoxin $B$ & $\begin{array}{c}\text { Myobloc Neurobloc (US WorldsMeds, } \\
\text { Solstice Neurosiences, Louisville, KY) }\end{array}$ \\
\hline
\end{tabular}

Table 1

THE COMPOSITION OF THE DIFFERENT COMMERCIAL TYPES OF TOXINUM BOTULINUM [25] balance in the affected limb. The maximum local toxin effect is reached in about 4 to 6 weeks and lasts approximately 12-16 weeks, which can be extended when accompanied by an appropriate rehabilitation program $[26,27]$.

In 1989, onabotulinumtoxin A or Botox was the first Food and Drug Administration (FDA) approved toxinum botulinum type A product for the treatment of strabismus, blepharospasm and 7 nerve disorders, including hemifacial spasm. However, in Romania, the only products containing botulinum toxin type A, approved by the National Medicines Agency (ANM) for spasticity of the upper limb in adults, are Xeomin and Dysport.

\section{Experimental part}

The observational study took place in the Rehabilitation Department of Elias Emergency University Hospital between October 2017 - January 2018. The study was approved by the Ethics Committee of Elias University Emergency Hospital (no. 11292/08.08.2017), taking into consideration the Good Practice Guideline. The patients involved in the study gave their consent to the use of the results for research purposes.

Sixty (60) patients were included in the study, each of them presenting upper limb post-stroke spasticity, up to 1 year after the stroke. The patients were divided based on the product of toxinum botulinum type $A$ injected in the spastic upper limb - Xeomin or Dysport. All patients received a total dose of 2 viols of toxinum botulinum type $A$, a 30 patients group receiving Xeomin and the other 30 patients group receiving Dysport. The target muscles were the upper limb flexors of the elbow, wrist and fingers. The local injections were performed under ultrasound guidance.

The parameters assessed were: Modified Ashworth Scale (MAS) and Activities of Daily Living Scale (ADL). MAS is the most used tool for measuring spasticity on a scale with levels from 0 to 4 , where 0 shows the absence of spasticity and 4 shows the maximum intensity, while the upper limb is fixed in flexion/extension. ADL Scale is composed of 11 items which include presumed personal care activities: bath and shower, dressing, food supply, eating, bladder and gutfunction management, maintaining the helping device, functional mobility, toilet hygiene, hygiene and personal care, rest and sleep, sexual activity.

As for the tests applied we need to mention that the data was of scale type and we used Mann-Whitney $U$ test to compare the differences between the two independent groups [28].

\section{Research protocol}

All patients were first evaluated at T0 (the initial time), when the toxinum botulinum type $A$ ultrasound guided injections were delivered after an evaluation of the patients for the target muscles. Hand function and local spasticity were evaluated using the MAS and the ADL Scale. Further evaluations were performed one month (T1) and three months (T2) after the injections, to measure the results on the MAS and ADL scale. In addition to comparing the results of injections with Dysport and Xeomin on the evaluation scales of the 2 groups, we aim to also evaluate if whether there is any difference in maintaining the local antispastic effect in time (T0 versus T3), between the products of botulinum toxin type $A$.

\section{Results and discussions}

Although toxinum botulinum has been clinically used for almost decades, there are still many unanswered questions. For example, what is the optimal starting dose? In the present study we want to compare the effect on spasticity and upper limb function of two products containing botulinum toxin: Xeomin (purified neurotoxin) and Dysport (botulinum toxin with accessory proteins).

The first generations of botulinum toxin preparations (Botox, Dysport) contain NAPs (neurotoxin-associated proteins), the second generation of botulinum toxin preparations (Xeomin) contain purified neurotoxin. Regarding the conversion ratio between the preparations the manufacturing, companies have not yet reached a consensus (fig. 1).

The results of the elemental analysis are presented in the following figures $2-8$ and tables $2-5$, followed by a comprehensive discussion.
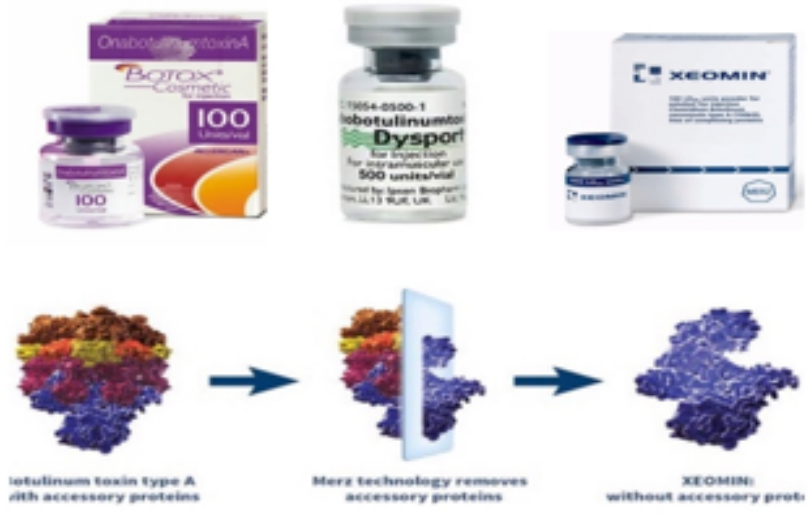

Fig. 1 Botulinum toxin preparations (BOTOX, DYSPORT, XEOMIN) 


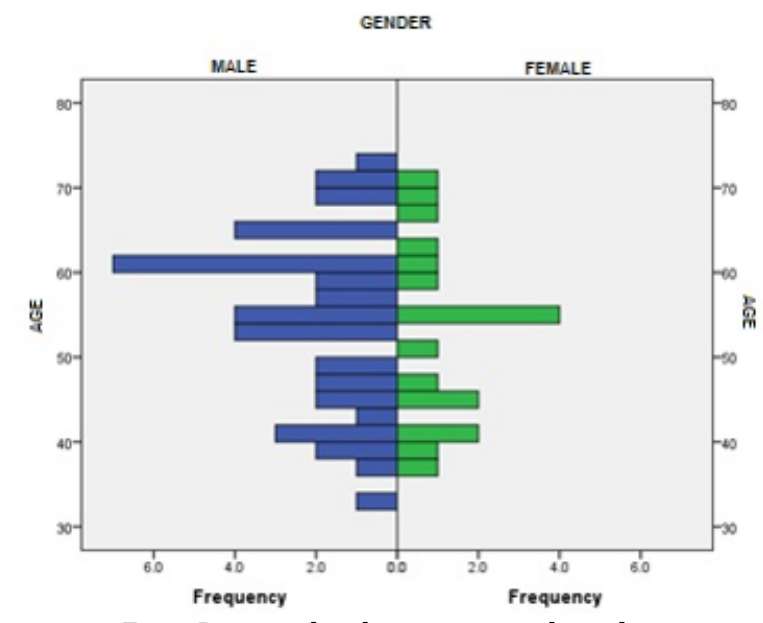

Fig. 2 Patients distribution: age and gender

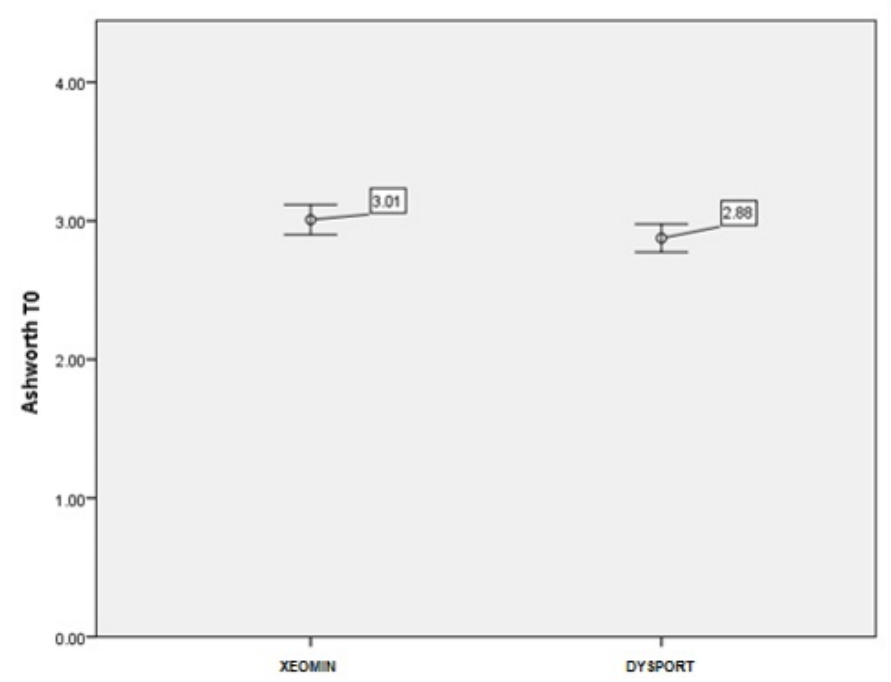

Fig. 3 Distribution of the MAS average at TO and the standard error depending on the preparation administered Xeomin / Dysport

Modified Aschworth Scale (MAS)

T0 measurement helps us to validate patients homogeneity. Afterwards, we will compare the values with the spasticity score on MAS at T2 ( 3 months after the first injection).

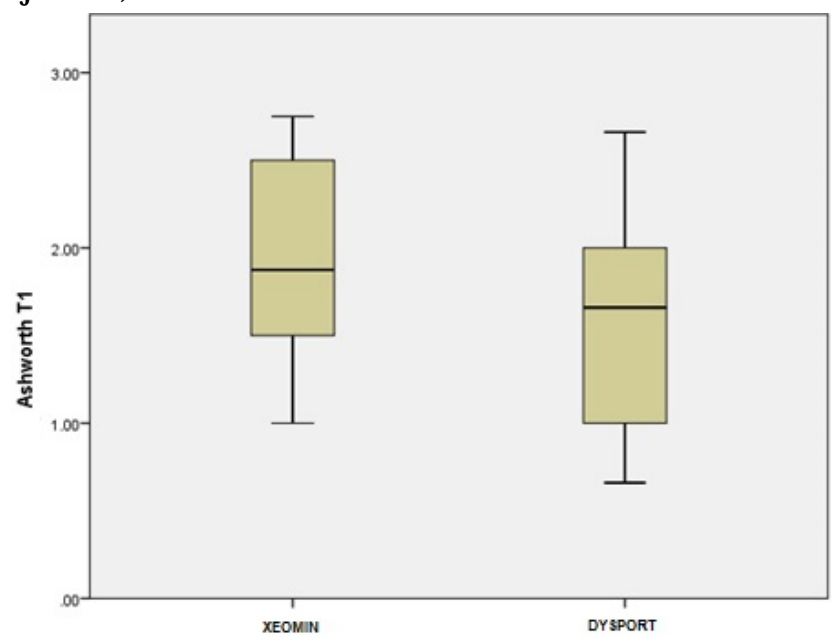

Fig. 4 Distribution of the MAS average at T1 and the standard error depending on the preparation administered Xeomin / Dysport
The group of patients that received Dysport had a better improvement in spasticity score than the other group: 1.63 versus 1.92 (Xeomin group) on the MAS. In terms of percentage changes, the difference is not relevant - an average decrease of 36 percentage points in Xeomin group vs. a 43 percentage points decrease in the Dysport group, without statistical significance.

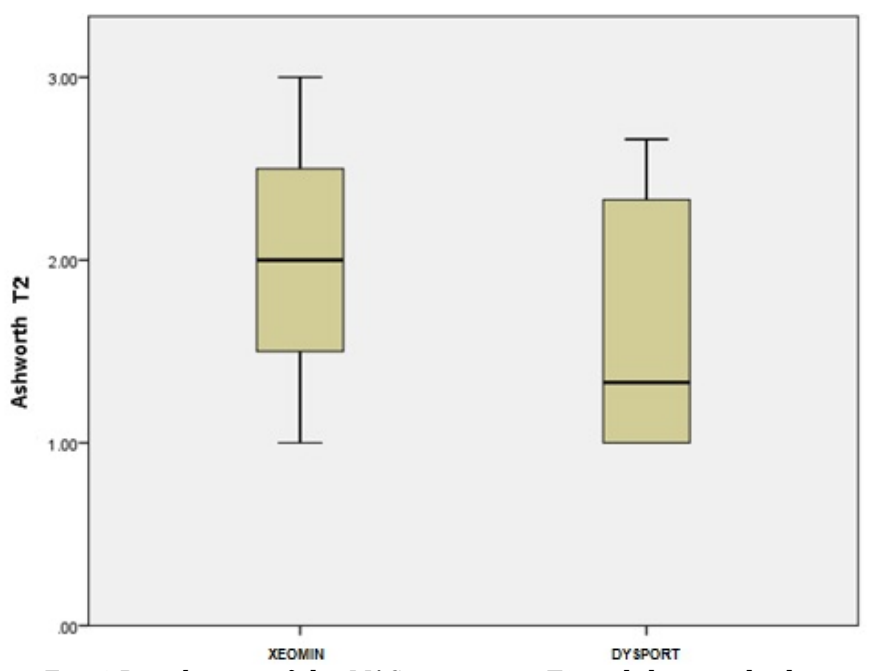

Fig. 5 Distribution of the MAS average at T2 and the standard error depending on the preparation administered Xeomin / Dysport

At T2 significant differences are observed between the two groups of patients, 3 months after T0 (the first injection). The group who received Xeomin had an average MAS score of 1.98, while the group who received Dysport had an average MAS score of 1.6. The difference regarding the median is even more visible.

\section{Activityes of Daily Living(ADL)}

We notice we have higher averages in the Dysportgroup, but the difference is not statistically relevant. $(p-0.078)$

Despite the fact that the ADL score had a minimal improvement after 1 month (TO), we registered a significant improvement at T2 (3 months). This can be explained by the fact that after 1 month of treatment, toxinum botulinum was effective to reduce the passive range of motion in the affected limb and, subsequentally, the patients were able to have a better intensity exercise and improve hand function with results seen at T3 (3 months), with high statistical relevance $(p-0.031)$.

Similar to the results obtained in the present study, in an 2015 published article, A. Santamato reviewed the efficiency of higher doses of toxinum botulinum type $A$ and concluded that higher doses had superior efficiency in reducing lower or upper limb spasticity after a stroke [29].

It has also been shown that toxinum botulinum type A injections administered after a stroke can produce good improvements in arm function [30]. Furthermore, according to a study published in 2011 by K.H. Eisele et al. [31], neurotoxin-associated proteins (NAPs) demonstrated the following characteristics: can dissociate in solution after reconstitution, have no protective effect against neurotoxin degradation, have no stabilizing effect for the active substance, do not inhibit the diffusion of neurotoxin into tissue after reconstitution, do not influence the effect Table 2

STATISTICAL COMPARISON OF MAS AT TI BASED ON PREPARATION ADMINISTERED XEOMIN / DYSPORT

\begin{tabular}{|l|c|c|c|c|c|c|c|c|}
\hline $\begin{array}{l}\text { Tl: } \\
\text { Ashworth }\end{array}$ & $\begin{array}{l}\text { No. of } \\
\text { patients }\end{array}$ & Average & Median & $\begin{array}{l}\text { Standard } \\
\text { deviation }\end{array}$ & $\begin{array}{l}\text { p-value for } \\
\text { normality }\end{array}$ & $\begin{array}{l}\text { Normal } \\
\text { distribution? }\end{array}$ & $\begin{array}{l}\text { Compara- } \\
\text { tive test }\end{array}$ & $\begin{array}{l}\text { Result } \\
\text { p-value }\end{array}$ \\
\cline { 1 - 6 } Xeomin & 30 & 1.92 & 1.88 & 0.5 & 0.116 & Yes & \multirow{2}{*}{$\begin{array}{c}\text { Mann- } \\
\text { Whitney U }\end{array}$} & $\mathbf{0 . 0 3 4}$ \\
\hline Dysport & 30 & 1.63 & 1.66 & 0.58 & 0.001 & No & Whinn \\
\hline
\end{tabular}


of neurotoxin, can determine the development of antibodies that decrease the therapeutic effect (2-5\%); also, in the same study it was highlighted that antibodies to Xeomin have not yet been described.

Xeomin and Dysport commercial preparations come in different concentrations. Whereas 1 vial of Dysport contains $500 \mathrm{IU}$, Xeomin contains $100 \mathrm{IU}$. The conversion rate between the 2 preparations according to the article published by Eisele et al. in Toxicon 2011 [31] is 4:1. Thus, the group of 30 patients injected with 2 vials of Dysport received a total dose of $1000 \mathrm{IU}$ of botulinum toxin at the level of the spastic upper limb, whilst those injected with 2 vials of Xeomin ( $200 \mathrm{IU}$ ) benefited by equating the 2 products according to 4:1 conversion rate of $800 \mathrm{IU}$ of Dysport, therefor a smaller amount of botulinum toxin. In conclusion, the better results obtained on the evaluation scales, by a more important decrease of spasticity at 1 month at time T1 and at T3, were expected - as well as a better improvement of hand function on the ADL scale.

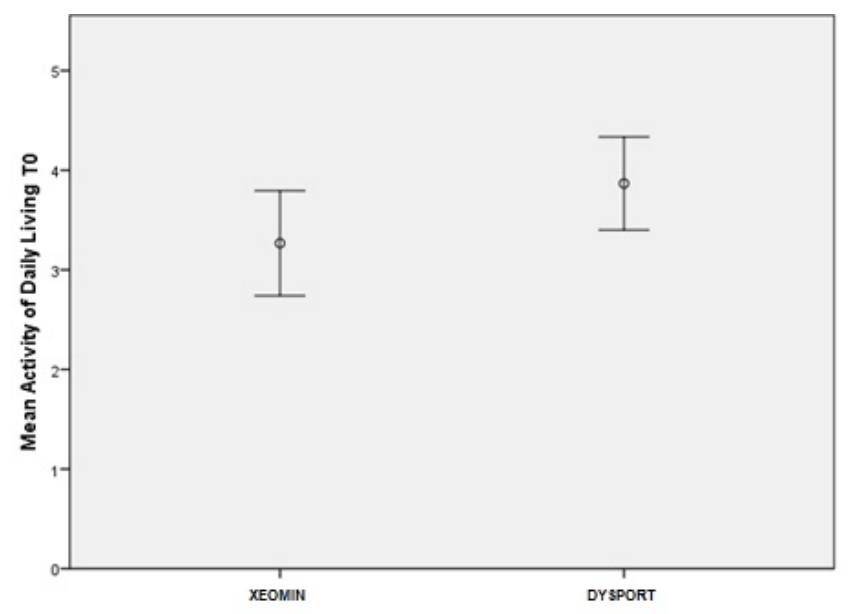

Fig. 6 Distribution of the ADL average at T0 and the standard error depending on the preparation administered Xeomin / Dysport

Table 3

STATISTICAL COMPARISON OF MAS AT T2 BASED ON PREPARATION ADMINISTERED XEOMIN / DYSPOR

\begin{tabular}{|l|l|c|c|c|c|c|c|c|}
\hline $\begin{array}{l}\text { T2: } \\
\text { Ashworth }\end{array}$ & $\begin{array}{l}\text { No. of } \\
\text { patients }\end{array}$ & Average & Median & $\begin{array}{l}\text { Standard } \\
\text { deviation }\end{array}$ & $\begin{array}{l}\text { p-value for } \\
\text { normality }\end{array}$ & $\begin{array}{l}\text { Normal } \\
\text { distribution? }\end{array}$ & $\begin{array}{l}\text { Comparative } \\
\text { test }\end{array}$ & $\begin{array}{l}\text { Result } \\
\text { p-value }\end{array}$ \\
\hline Xeomin & 30 & 1.98 & 2 & 0.58 & 0.11 & Yes & Mann-Whitney & \multirow{2}{*}{ U } \\
\hline Dysport & 30 & 1.6 & 1.33 & 0.64 & $<0.001$ & No & U & $\mathbf{0 . 0 2 4}$ \\
\hline
\end{tabular}

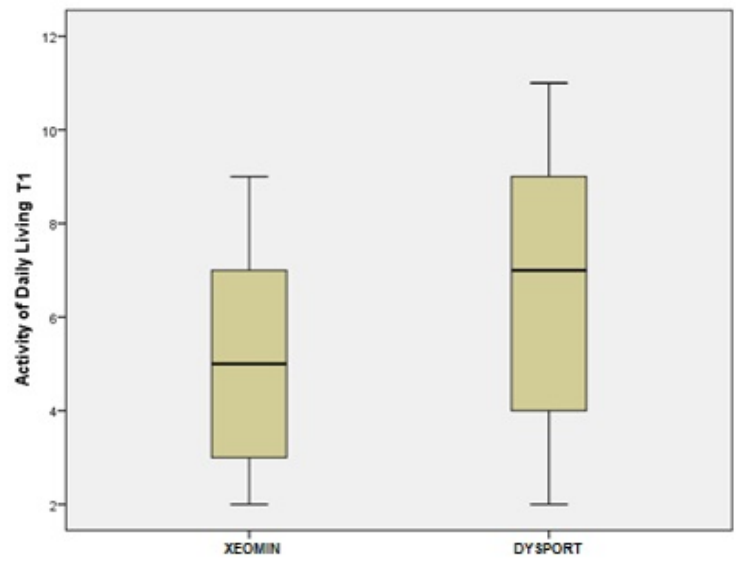

Fig. 7 Distribution of the ADL average at T1 and the standard error depending on the preparation administered Xeomin / Dysport

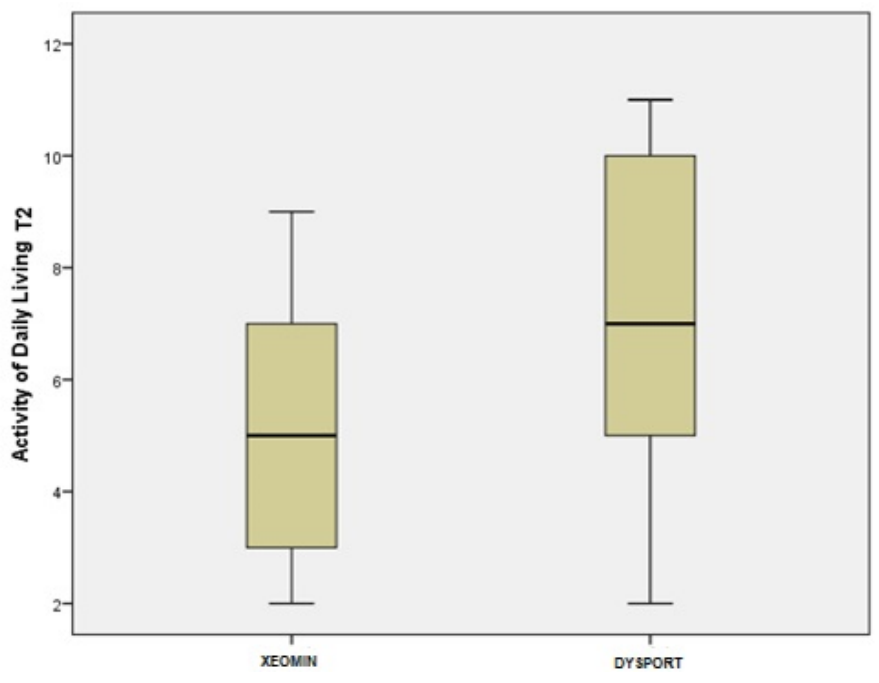

Fig. 8 Distribution of the ADL average at $\mathrm{T} 2$ and the standard error depending on the preparation administered Xeomin / Dysport

Table 4

STATISTICAL COMPARISON OF ADL AT T1 BASED ON PREPARATION ADMINISTERED XEOMIN / DYSPORT

\begin{tabular}{|l|l|l|l|l|l|l|l|l|}
\hline Tl: ADL & $\begin{array}{l}\text { No. of } \\
\text { patients }\end{array}$ & Average & Median & $\begin{array}{l}\text { Standard } \\
\text { deviation }\end{array}$ & $\begin{array}{l}\text { p-value for } \\
\text { normality }\end{array}$ & $\begin{array}{l}\text { Normal } \\
\text { distribution? }\end{array}$ & $\begin{array}{l}\text { Comparative } \\
\text { test }\end{array}$ & $\begin{array}{l}\text { Result } \\
\text { p-value }\end{array}$ \\
\hline Xeomin & 30 & 5.23 & 5 & 2.285 & 0.097 & Yes & \multirow{2}{*}{ Mann-Whitney } & \\
\cline { 1 - 7 } Dysport & 30 & 6.47 & 7 & 2.751 & 0.002 & No & U & 0.078 \\
\hline
\end{tabular}

Table 5

STATISTICAL COMPARISON OF ADL AT T2 BASED ON PREPARATION ADMINISTERED XEOMIN / DYSPORT

\begin{tabular}{|l|c|c|c|c|c|l|l|l|}
\hline T2: ADL & $\begin{array}{l}\text { No. of } \\
\text { patients }\end{array}$ & Average & Median & $\begin{array}{l}\text { Standard } \\
\text { deviation }\end{array}$ & $\begin{array}{l}\text { p-value for } \\
\text { normality }\end{array}$ & $\begin{array}{l}\text { Normal } \\
\text { distribution? }\end{array}$ & $\begin{array}{l}\text { Compara- } \\
\text { tive test }\end{array}$ & $\begin{array}{l}\text { Result } \\
\text { p-value }\end{array}$ \\
\hline Xeomin & 30 & 5.4 & 5 & 2.298 & 0.043 & No & \multirow{2}{*}{$\begin{array}{c}\text { Mann- } \\
\text { Whitney U }\end{array}$} & $\mathbf{0 . 0 3 1}$ \\
\hline Dysport & 30 & 7.03 & 7 & 3.034 & 0.2 & Yes & \\
\hline
\end{tabular}

The most interesting thing is the duration of the effect. The present study shows that a higher dose of botulinum toxin, although showing a greater improvementin reducing spasticity and improving hand function, does not translate with a longer period of maintenance of the local antispastic 
The same analogy applies to different botulinum toxinum preparations, Xeomin (purified neurotoxin) and Dysport (neurotoxin with associated protein complex).

During the course of the study, the adverse effects reported by the patients were very rare and minor, largely related to pain at the injection site. Considering that literature data does not show a well-defined role of botulinum toxin preparations with associated protein complexes and also taking into account the development of antibodies in 2-5\% cases, we believe that further larger studies will be needed, with a more detailed statistical quantification of the adverse effects caused by botulinum toxin administration and titration of botulinum toxin antibodies.

\section{Conclusions}

Both preparations of botulinum toxin type A Xeomin and Dysport, used in the present study, confirmed their good efficiency in treating post-stroke spasticity.

A very interesting conclusion is that the period of maintenance of the antispastic effect in the affected limb after stroke was not influenced by the different preparations of botulinum toxin, purified neurotoxin vs. neurotoxin with associated protein complex, nor the different doses used.

The safety of administering the two commercial botulinum toxin type A preparations was certified by the small number of minor adverse effects reported, all related to pain at the injection site. The study did not record any systemic adverse effects.

\section{References}

1.MALHOTRA, S., PANDYAN, A.D., DAY, C.R., JONES, P.W., HERMENS, H. Clin. Rehabil., 23, no. 7, 2009, p. 651.

2.FELDMAN, R.G., YOUNG, R.R., KOELLA, W.P. Spasticity: Disordered Motor Control. Year Book Medical Publishers, Chicago, p.185-204

3.ADA, L., O'DWYER, N., O'NEILL, E. Disabil. Rehabil., 28, no. 13-14, 2006, p. 891.

4.SHAW, L.C., PRICE, C., VAN WIJCK, F.M., SHACKLEY, P., STEEN, N., et al., Stroke, 42, no. 5, 2011, p. 1371.

5.FRANCISCO, G.E., MCGUIRE, J.R. Stroke, 43, no. 11, 2012, p. 3132. 6.RUSU, M. C., POP, F., HOSTIUC, S., MANTA, L., MARU, N., GRIGORIU, M. Rom. J. Morphol. Embryol., 59, no. 3, 2018, p. 663.

7.ASHFORD, S., JACKSON, D., TURNER-STOKES, L. Physiotherapy, 101 , no. 1, 2015, p. 88.

8.ZGURA, A., GALES, L., HAINEALA, A. B., BRATILA, E., MEHEDINTU, C., et al. Rev. Chim.(Bucharest), 70, no. 7, 2019, p. 2362

9.BARNES, M.P., JOHNSON, G.R. Upper Motor Neurone Syndrome and spasticity, $2^{\text {nd }}$ ed. Cambridge University Press, New York, NY, 2008, p. $165-180$.
10.REKAND, T. Acta Neurol. Scand., 122, suppl. 190, 2010, p. 62. 11.STEVENSON, V., PLAYFORD, D. Medicine, 40, no. 9, 2012, p. 513. 12.BRASHEAR, A., LAMBETH, K. Curr. Treat. Options Neurol., 11, no. 3, 2009, p. 153.

13.PETCA, A., RADU, D. C., PETCA, R. C., MEHEDINTU, C., BARAC, R. I., et al. Rev. Chim.(Bucharest), 70, no. 6, 2019, p. 2021.

14.J ANKOVIC, J., HALLETT, M., eds. Therapy with botulinum toxin. Marcel Dekker, Inc., New York, NY, 1994, p. 15-39.

15.MEHEDINTU, C., BRATILA, E., CIRSTOIU, M., PETCA, A., BRINDUSE, L. A., et al. Rev. Chim.(Bucharest), 70, no. 7, 2019, p. 2375

16.BRIN, M.F., HALLETT, M., JANKOVIC, J. eds. Scientific and therapeutic aspects of botulinum toxin. LippincottW illiams $\&$ Wilkins, Philadelphia, PA, 2002, p.1-507.

17.PRODEA, M. C., SANDRU, F., CARPENCO, E., GAJ E, P. N., HORHAT, I. D., et al. Rev. Chim.(Bucharest), 70, no. 5, 2019, p. 1863.

18.J ANKOVIC, J ., ALBANESE, A., ATASSI, M.Z., DOLLY, J ., HALLETT, M., MAYER, N., eds. Botulinum toxin: Therapeutic clinical practice and science. Saunders, Philadelphia, PA; London, 2009, p.1-492

19.ARNON, S.S., SCHECHTER, R., INGLESBY, T.V., HENDERSON, D.A., BARTLETT, J.G., et al. JAMA, 285, no. 8, 2001, p.1059.

20.J ABBARI, B. Tremor Other Hyperkinet. Mov. (N Y), 6, 2016, doi: 10.7916/D81836S1.

21.SCHANTZ, E.J., JOHNSON, E.A. Microbiol. Rev., 56, no. 1, 1992, p. 80.

22.ROSSETTO, O., PIRAZZINI, M., MONTECUCCO, C. Toxicon, 107, (Pt A), 2015, p. 59.

23.PADURARU, D. N., BOUARIU, A., ION, D., DUMITRASCU, M. C., NITIPIR, C., et al. Rom. Biotechnol. Lett., 23, no. 5, 2018, p. 14056. 24.PIRAZZINI, M., ROSSETTO, O., ELEOPRA, R., MONTECUCCO, C., Pharmacol. Rev., 69, no. 2, 2017, p. 200.

25.KATHERINE, E.A, KARP, B., LUNGU, C., HALLET, M. Ultrasoundguided chemodenervation procedures: text and atlas., Demos Medical, New York, NY, 2013, p. 10-13.

26.WARD, A.B., WISSEL, J., BORG, J., ERTZGAARD, P., HERMANN, C., et. al. J. Rehabil. Med., 46, no. 5, 2014, p. 504.

27.TROMPETTO, C., MARINELLI, L., MORI, L., PUCE, L., PELOSIN, E., et al. Med. Hypotheses., 102, 2017, p. 28.

28.VEDUTA, A., PETCA, R., PETCA, A. Proceedings Of The 14th National Congress Of Urogynecology And The National Conference Of The Romanian Association For The Study Of Pain, Eforie, Romania, 2017, p. 199.

29.SANTAMATO, A., MICELLO, M.F., RANIERI, M., VALENO, G., ALBANO, A., et. al. J. Neurol. Sci., 350, no. 1-2, 2015, p. 1.

30.COUSINS, E., WARD, A., ROFFE, C., RIMINGTON, L., PANDYAN, A. Clin. Rehabil., 24, 2010, p. 501.

31.EISELE, K.H, FINK, K., VEY, M., TAYLOR, H.V. Toxicon, 57, no. 4, 2011, p. 555.

Mauscript received: 8.09 .2019 